\title{
Hsp90 inhibitor SY-016 induces G2/M arrest and apoptosis in paclitaxel-resistant human ovarian cancer cells
}

\author{
HYUN GYO LEE ${ }^{1}$, WON JIN PARK ${ }^{2}$, SO JIN SHIN ${ }^{2}$, SANG HOON KWON ${ }^{2}$, SOON DO CHA ${ }^{2}$, \\ YOUNG HO SEO ${ }^{3}$, JU HUI JEONG ${ }^{3}$, JI YOON LEE ${ }^{1}$ and $\mathrm{CHI} \mathrm{HEUM} \mathrm{CHO}^{1,2}$ \\ ${ }^{1}$ Institute for Cancer Research; ${ }^{2}$ Department of Obstetrics and Gynecology, Keimyung University School of Medicine, \\ Daegu 41931; ${ }^{3}$ College of Pharmacy Keimyung University, Daegu 42601, Republic of Korea
}

Received June 5, 2015; Accepted October 12, 2016

DOI: $10.3892 / \mathrm{ol} .2017 .5794$

\begin{abstract}
The aim of the present study was to evaluate the in vitro effect of a heat shock protein (Hsp)90 inhibitor, SY-016, on the paclitaxel (PTX)-resistant human ovarian cancer cell line OVCAR-3PTX, and explore its mechanism of apoptosis. In the present study, SY-016 was used in combination with PTX to determine its effect on the cell proliferation and apoptosis of OVCAR-3PTX cells. The drug-resistant tumor cells were established in vitro by stepwise sequential exposure to increasing concentrations of PTX. The cell viability and cell cycle distribution were measured by MTT assay and flow cytometric analysis, respectively. The induction of apoptosis was measured by caspase- 3 activity, DNA fragmentation and western blot analyses. The cell viability significantly decreased following treatment with PTX and SY-016 as compared with either drug alone. The DNA fragmentation assay revealed an induction of apoptosis. The results from the flow cytometric analysis revealed an increase in the percentage of cells in the G2/M phase. Downregulation of B-cell lymphoma (Bcl)-2, $\mathrm{X}$-linked inhibitor of apoptosis protein, survivin, Akt, nuclear factor- $\kappa \mathrm{B}$ and cyclin-dependent kinase 4 , as well as upregulation of Bcl-2-associated X protein, were observed. SY-016 may contribute to the induction of apoptosis in OVCAR-3PTX cells. These results suggest that SY-016 in combination with PTX may be a beneficial chemotherapeutic strategy, particularly in patients with tumors refractory to PTX.
\end{abstract}

\section{Introduction}

Ovarian cancer is the fifth most common cause of cancer mortality in women (1). Although tumor-reductive surgery and cisplatin- and paclitaxel (PTX)-based chemotherapy regimens are effective treatments for primary disease, recurrence of the

Correspondence to: Dr Chi Heum Cho, Department of Obstetrics and Gynecology, Keimyung University School of Medicine, 56 Dalseong-ro, Daegu 41931, Republic of Korea

E-mail: c0035@dsmc.or.kr

Key words: ovarian cancer, Hsp90, inhibitor, resistance, apoptosis disease is observed in the majority of ovarian cancer patients, which often leads to mortality (2).

PTX is a natural antitumor agent. Since its clinical applications in the $1990 \mathrm{~s}$, treatment with PTX in combination with a platinum compound has become the standardized front-line chemotherapy for ovarian epithelial cancer patients (2). PTX binds $\beta$-tubulin, promoting tubulin polymerization and microtubulin assembly, thereby inhibiting the completion of mitosis, inducing G2/M phase arrest and eventually causing cell apoptosis (3). However, its clinical efficacy has been hampered due to the development of multidrug resistance in tumors. Consequently, dose-limiting toxicities often prevent patients from receiving optimal clinical benefits (3).

Resistance to platinum-based or platinum-taxane combination chemotherapy is one of the major causes of treatment failure in ovarian cancer (4). Multidrug resistance occurs when a non-drug-resistant cell becomes cross-resistant to drugs of other classes upon being treated with a single drug. The efflux pump P-glycoprotein can increase the removal of anticancer drugs from cancer cells, resulting in a reduction in intracellular drug accumulation by active extrusion of drugs from the cells (5). Therefore, it is required to identify a drug that can overcome chemoresistance and sensitize ovarian cancer to the antitumor effect of PTX.

Heat shock protein (Hsp)90 is a molecular chaperone that is important for the post-translational stability and function of numerous proteins, which serve critical roles in cell growth, differentiation and survival (6). Since multiple signal transduction cascades are regulated by this molecule, the effects of pharmacological blockade of Hsp90 are transmitted to intracellular signaling pathways (7). Hsp90 has been demonstrated to bind to apoptotic protease activating factor-1, which in turn inhibits the apoptosome complex formation and leads to the prevention of the apoptotic protease cascade (8). Recent cancer research is focused on the development of new drugs that can overcome the ability of cancer cells to bypass the execution of apoptosis. Hsp90 represents an attractive molecular target for the development of novel anticancer agents (9). To this end, several approaches have been launched using a combination of current drugs and apoptosis sensitizers. In addition, since tumor cells contain elevated levels of the active form of the Hsp90 chaperone complex compared with normal cells, tumor cells have been shown to be selectively sensitive to Hsp90 inhibition (10). 
In the present study, the effects of a novel Hsp90 inhibitor, SY-016, on the PTX-resistant human ovarian cancer cell line OVCAR-3PTX were investigated. Changes in apoptosis-related proteins and signal transduction pathways were examined with the aim of elucidating the mechanism by which SY-016 mediates the induction of apoptosis.

\section{Materials and methods}

Cell culture and chemicals. The human ovarian cancer cell line OVCAR-3 was purchased from the American Type Culture Collection (Manassas, VA, USA) and was grown as a monolayer in RPMI 1640 medium supplemented with $1 \%$ (w/v) penicillin/streptomycin and $10 \%(\mathrm{v} / \mathrm{v})$ fetal bovine serum (FBS) at $37^{\circ} \mathrm{C}$ in a $5 \% \mathrm{CO}_{2}$ humidified atmosphere. The human ovarian cancer cell line A2780 and the cisplatin-resistant ovarian cancer cell line A2780cis were obtained from the European Collection of Animal Cell Cultures (Salisbury, UK) and maintained as described previously (11). PTX and cisplatin were purchased from Sigma-Aldrich (Merck Millipore, Darmstadt, Germany). FBS, penicillin/streptomycin solution, trypsin and RPMI 1640 medium were purchased from HyClone (GE Healthcare Life Sciences, Logan, UT, USA).

\section{SY-016 synthesis}

1-(2,4-Dyhydroxy-5-isopropylphenyl) ethanone. A mixture of 2,4-dihydroxyacetophenone $(2.0 \mathrm{~g}, 13.1 \mathrm{mmol}), 2$-bromopropane $(2.47 \mathrm{ml}, 26.3 \mathrm{mmol})$, and aluminum chloride $(3.5 \mathrm{~g}$, $26.3 \mathrm{mmol}$ ) in $\mathrm{CH}_{2} \mathrm{Cl}_{2}$ was stirred at $50^{\circ} \mathrm{C}$ for $12 \mathrm{~h}$ in a reflux condenser under argon. 2-Bromopropane $(2.47 \mathrm{ml}, 26.3 \mathrm{mmol})$ was added to the reaction mixture three times every $6 \mathrm{~h}$. The mixture was neutralized with $10 \% \mathrm{NaOH}$ to $\mathrm{pH} 5.0$ and then extracted with ethyl acetate. The organic layer was washed with water three times, dried over $\mathrm{Na}_{2} \mathrm{SO}_{4}$, concentrated under reduced pressure and purified by medium pressure liquid chromatography (MPLC) to obtain compound 1 with a $46 \%$ yield. The ratio of the distance traveled by compound and the distance moved by solvent on the thin-layer chromatography plate $\left(\mathrm{R}_{\mathrm{f}}\right)=0.33$ (1:4 ethyl acetate:hexane). ${ }^{1} \mathrm{H}$ nuclear magnetic resonance $(\mathrm{NMR})\left(400 \mathrm{MHz}, \mathrm{CDCl}_{3}\right): \delta 12.61(\mathrm{~s}, 1 \mathrm{H}), 7.52(\mathrm{~s}$, $1 \mathrm{H}), 6.35$ (s, 1H), 6.31 (s, 1H), 3.22-3.12 (m, 1H), 2.61 (s, 3H), 1.27 (d, $J=6.8 \mathrm{~Hz}, 6 \mathrm{H})$. Electrospray ionization (ESI) mass spectrometry $(\mathrm{MS})(\mathrm{me})=195[\mathrm{M}+1]^{+}$.

1-(2,4-Bis(allyloxy)-5-isopropylphenyl) ethanone. A mixture of compound 1 ( $0.1 \mathrm{~g}, 0.52 \mathrm{mmol})$, allyl bromide $(1.4 \mathrm{~g}, 1.3 \mathrm{mmol})$ and potassium carbonate $(0.19 \mathrm{~g}, 1.3 \mathrm{mmol})$ in dimethylformamide was stirred for $18 \mathrm{~h}$. The solvent was removed under reduced pressure, and the remaining residue was dissolved in ethyl acetate. The organic layer was washed with saturated $\mathrm{NaHCO}_{3}$ solution, dried over $\mathrm{Na}_{2} \mathrm{SO}_{4}$, concentrated under reduced pressure and purified by MPLC to obtain compound 2 with a $99 \%$ yield. $\mathrm{R}_{\mathrm{f}}=0.45$ (1:9 ethyl acetate:hexane). ${ }^{1} \mathrm{H}$ NMR (400 $\left.\mathrm{MHz}, \mathrm{CDCl}_{3}\right): \delta 7.73(\mathrm{~s}, 1 \mathrm{H})$, $6.39(\mathrm{~s}, 1 \mathrm{H}), 6.12-6.01(\mathrm{~m}, 2 \mathrm{H}), 5.46(\mathrm{~s}, 1 \mathrm{H}), 5.42(\mathrm{~s}, 1 \mathrm{H})$, 5.34-5.30 (m, 2H), 4.62-4.58 (m, 4H), 3.27-3.18 (m, 1H), 2.60 $(\mathrm{s}, 3 \mathrm{H}), 1.20(\mathrm{~d}, J=7.2 \mathrm{~Hz}, 6 \mathrm{H})$. ESI MS $(m e)=275[\mathrm{M}+1]^{+}$.

(E)-1-(2,4-Bis(allyloxy)-5-isopropylphenyl)-3-phenylprop2-en-1-one. A mixture of compound 2 (0.21 g, $0.75 \mathrm{mmol})$, benzaldehyde $(0.094 \mathrm{~g}, 0.83 \mathrm{mmol})$ and $\mathrm{KOH}(4.0 \mathrm{~g})$ in $2 \mathrm{ml}$ water and $10 \mathrm{ml}$ ethanol was stirred for $1 \mathrm{~h}$. The mixture was

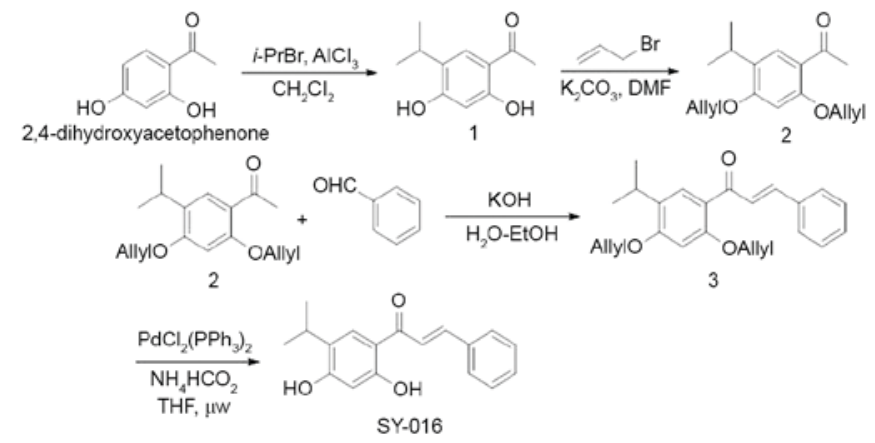

Figure 1. Synthesis of SY-016. $i \mathrm{Pr}-\mathrm{Br}$, isopropyl bromide; DMF, dimethylformamide; THF, tetrahydrofuran; $\mu \mathrm{w}$, microwave irradiation.

neutralized with $6 \mathrm{~N} \mathrm{HCl}$ to $\mathrm{pH} 6.0$ and then extracted with ethyl acetate. The organic layer was washed with saturated $\mathrm{NaHCO}_{3}$ solution three times, dried over $\mathrm{Na}_{2} \mathrm{SO}_{4}$, concentrated under reduced pressure and purified by MPLC (SNAP HP-Sil column; Biotage, Uppsala, Sweden) to obtain compound 3. ${ }^{1} \mathrm{H}$ NMR (400 MHz, $\left.\mathrm{CDCl}_{3}\right): \delta 7.71(\mathrm{~d}, J=15.8 \mathrm{~Hz}, 1 \mathrm{H}), 7.70$ (s, 1H), $7.65(\mathrm{~d}, J=15.8 \mathrm{~Hz}, 1 \mathrm{H}), 7.60-7.58$ (m, 2H), 7.39-7.36 (m, 3H), 6.45 (s, 1H), 6.12-6.02 (m, 2H), 5.48-5.42 (m, 2H), 5.34-5.26 (m, 2H), 4.63-4.60 (m, 4H), 3.12-3.25 (m, 1H), 1.24 $(\mathrm{d}, J=7.3 \mathrm{~Hz}, 6 \mathrm{H}) .{ }^{13} \mathrm{C} \mathrm{NMR}\left(100 \mathrm{MHz}, \mathrm{CDCl}_{3}\right): \delta 190.7,160.4$, 157. $9,141.5,135.7,132.9,132.9,130.3,130.0,129.3,129.0$, $128.5,127.7,121.7,118.1,117.7,97.5,70.0,69.1,26.8,22.7$. ESI $\mathrm{MS}(m e)=363[\mathrm{M}+1]^{+}$.

(E)-1-(2,4-Dihydroxy-5-isopropylphenyl)-3-phenylprop-2en-1-one. The resulting compound 3 was stirred under microwave irradiation (Initiator; Biotage) for $30 \mathrm{~min}$ at $120^{\circ} \mathrm{C}$ in the presence of $\mathrm{PdCl}_{2}\left(\mathrm{PPh}_{3}\right)_{2}(10 \mathrm{mg})$ and ammonium formate $(150 \mathrm{mg})$ in $4 \mathrm{ml}$ tetrahydrofuran. The reaction mixture was diluted with ethyl acetate. The organic layer was washed with water, dried over $\mathrm{Na}_{2} \mathrm{SO}_{4}$, concentrated under reduced pressure and purified by MPLC to obtain compound SY-016 with a $32 \%$ yield in two steps. ${ }^{1} \mathrm{H}$ NMR $\left(400 \mathrm{MHz}, \mathrm{CDCl}_{3}\right): \delta 13.29$ (bs, 1H), 7.89 (d, J=15.4 Hz, 1H), 7.69-7.65 (m, 3H), 7.59 (d, $J=15.4 \mathrm{~Hz}, 1 \mathrm{H}), 7.46-7.43$ (m, 3H), 6.39 (s, 1H), 6.20 (bs, 1H), 3.22-3.16 (m, 1H), $1.30(\mathrm{~d}, J=6.8 \mathrm{~Hz}, 6 \mathrm{H}) .{ }^{13} \mathrm{C}$ NMR $(100 \mathrm{MHz}$, $\left.\mathrm{CDCl}_{3}\right): \delta 192.1,164.3,160.8,144.4,134.8,130.7,129.0,128.6$, $128.0,127.0,120.4,114.2,103.6,26.9,22.6$. ESI MS $(m e)=283$ $[\mathrm{M}+1]^{+}$(Fig. 1).

Establishment of a cell line model with acquired resistance to PTX. The PTX-resistant ovarian cancer cell line OVCAR-3PTX was induced by continuous exposure of OVCAR-3 cells to PTX at low concentrations, which were gradually increased. When the cells were in logarithmic growth phase, PTX was added to the medium to a final concentration of $20 \mathrm{nM}$. After $48 \mathrm{~h}$ of incubation, the old medium was discarded, and fresh medium was added. Cells were passed when they were $80 \%$ confluent, and PTX (20 nM) was then added. The concentration of PTX was gradually increased once the cells had grown stably. Finally, a cell line resistant to $100 \mathrm{nM}$ PTX was derived from the OVCAR-3 cell line, and was maintained in complete medium containing $10 \mathrm{nM}$ PTX.

Cell viability assay. The number of viable cells exposed to Hsp90 inhibitor were evaluated by a colorimetric MTT assay. 
A

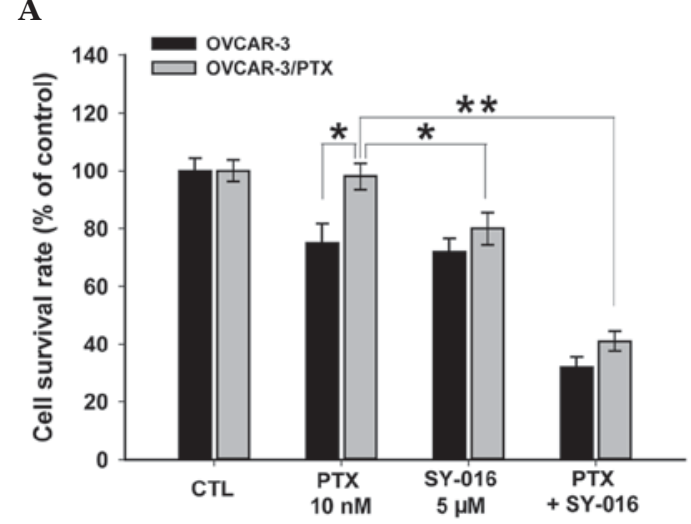

B

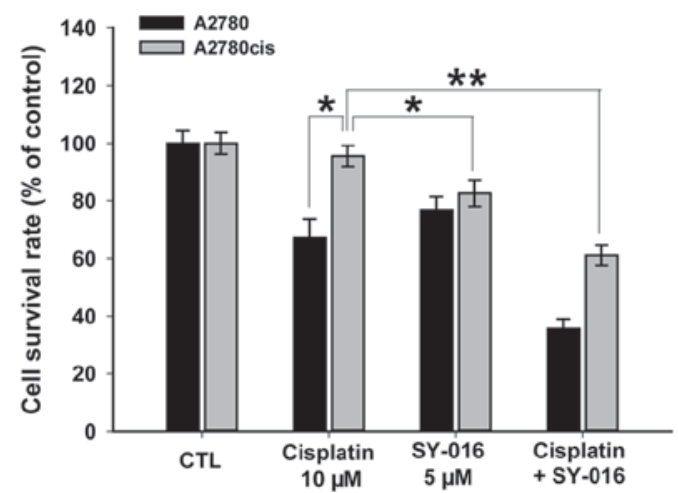

Figure 2. SY-016 inhibits cell proliferation in human ovarian cancer cells. (A and B) Proliferation of (A) OVCAR-3 and OVCAR-3PTX and (B) A2780 and A2780cis cell lines treated with PTX $(10 \mathrm{nM})$ and/or SY-016 $(5 \mu \mathrm{M})$ was observed for $48 \mathrm{~h}$. Cell viability was measured using the MTT assay. Values are means \pm standard deviation of three measurements ${ }^{*} \mathrm{P}<0.05 ;{ }^{* *} \mathrm{P}<0.005$. PTX, paclitaxel; CTL, control; cis; cisplatin.

The intensity of the purple color formed by this assay is proportional to the number of viable cells. A total of $5 \times 10^{4}$ OVCAR-3 cells were seeded in 24-well plates and treated for $48 \mathrm{~h}$ with PTX or SY-016, and then with $0.5 \mathrm{mg} / \mathrm{ml} \mathrm{MTT.} \mathrm{The} \mathrm{optical}$ density (OD) was then measured at $540 \mathrm{~nm}$. The mean value and standard deviation (SD) were calculated from triplicate experiments.

Determination of cell cycle distribution. To determine the distribution of cells in the different phases of the cell cycle, profile fluorescence-activated cell sorting analysis was performed. OVCAR-3PTX cells $\left(4-5 \times 10^{5}\right)$ were seeded in 6-well plates and treated with $10 \mathrm{nM}$ PTX and/or $5 \mu \mathrm{M}$ SY-016 for $48 \mathrm{~h}$. Next, cells were harvested by trypsinization and centrifugation (500 $\mathrm{x} g$ at room temperature for $5 \mathrm{~min}$ ), washed with cold PBS, and fixed in ice-cold $70 \%$ ethanol at $4^{\circ} \mathrm{C}$ for $24 \mathrm{~h}$. Ethanol-fixed cells were washed and treated with RNase A for $30 \mathrm{~min}$ at $37^{\circ} \mathrm{C}$. Subsequently, cells were stained with propidium iodide and incubated for $30 \mathrm{~min}$ at room temperature. DNA fluorescence was measured by flow cytometry (FACSCalibur ${ }^{\mathrm{TM}}$; BD Biosciences, Franklin Lakes, NJ, USA).

Protein extraction and western blot analysis. Hsp90 inhibitor-treated cells were harvested in $1 \mathrm{X}$ radioimmunoprecipitation assay buffer containing protease and phosphatase inhibitors with EDTA (Thermo Fisher Scientific, Inc., Waltham, MA, USA). Protein concentrations were measured using Protein Assay Dye Reagent Concentrate (Bio-Rad Laboratories, Inc., Hercules, CA, USA) following the manufacturer's protocol. The cell lysates were mixed with 4X sample buffer, boiled for $10 \mathrm{~min}$ and then separated by electrophoresis on $10-12 \%$ SDS polyacrylamide gels. After electrophoresis, the proteins were transferred to nitrocellulose membranes. The membranes were blocked with 5\% skimmed milk powder in Tris-buffered saline with Tween-20 at room temperature for $1.5 \mathrm{~h}$ and then incubated overnight at $4^{\circ} \mathrm{C}$ with the following primary antibodies: Anti- $\beta$-actin $(1: 10,000$; Sigma-Aldrich; Merck Millipore), anti-Hsp70 (1:1,000; Cell Signaling Technology, Inc., Danvers, MA, USA), anti-Hsp90 (1:1,000; Cell Signaling Technology, Inc.), anti-Akt (1:1,000; Cell Signaling Technology, Inc.), anti-nuclear factor (NF)- $\mathrm{B}$
(1:1,000; Cell Signaling Technology, Inc.), anti-B-cell lymphoma (Bcl)-2 (1:1,000; Santa Cruz Biotechnology, Inc., Dallas, TX, USA), anti-Bcl-2-associated X protein (Bax) (1:1,000; BD Pharmingen, San Diego, CA, USA), anti-X-linked inhibitor of apoptosis protein (XIAP) $(1: 1,000$; BD Pharmingen), anti-cyclin-dependent kinase (CDK)4 (1:1,000; Santa Cruz Biotechnology, Inc.) and anti-survivin (1:1,000; Santa Cruz Biotechnology, Inc.). The blots were next incubated with horseradish peroxidase-conjugated secondary antibodies (Santa Cruz Biotechnology, Inc.) at room temperature for $2 \mathrm{~h}$, and signals were detected with SuperSignal West Pico Chemiluminescent Substrate (Thermo Fisher Scientific, Inc.). The densitometry of the bands was determined using a ChemiDoc XRS+ imaging system (Bio-Rad Laboratories, Inc.) and normalized to $\beta$-actin, which served as the loading control.

Colorimetric assay of caspase-3 activity. Following drug treatment, cells were centrifuged at $500 \mathrm{x} \mathrm{g}$ for $5 \mathrm{~min}$ and harvested. Cells $\left(2 \times 10^{6}\right)$ were then lysed in $50 \mu 1$ lysis buffer, which was from the Caspase Colorimetric Assay kit (Clontech Laboratories, Inc., Mountainview, CA, USA) on ice for $10 \mathrm{~min}$ and centrifuged at $10,000 \times \mathrm{g}$ for $5 \mathrm{~min}$ at $4^{\circ} \mathrm{C}$, and the supernatant was then collected. The supernatant $(50 \mu \mathrm{l})$ was added to an equal volume of $2 \mathrm{X}$ dithiothreitol solution supplemented with Asp-Glu-Val-Asp p-nitroanilide (pNA) (50 $\mu \mathrm{M}$; Caspase Colorimetric Assay kit) and incubated at $37^{\circ} \mathrm{C}$ for $3 \mathrm{~h}$. Caspase- 3 activity was measured as the absorbance at $405 \mathrm{~nm}$ of the cleaved substrate pNA, according to the protocol of the Caspase Colorimetric Assay kit (Clontech Laboratories, Inc.).

DNA fragmentation assay. Fragmented nucleosomal DNA was quantified with the Cell Death Detection ELISAPLUS kit (Roche Diagnostics GmbH, Mannheim, Germany) as described in the manufacturer's manual. Supernatant $(20 \mu \mathrm{l})$ was used to detect apoptosis with a microplate reader (Tecan Austria $\mathrm{GmbH}$, Grödig, Austria) at $405 \mathrm{~nm}$. Background values were subtracted, and OD values representing nucleosomal DNA fragments in Hsp90 inhibitor-treated samples were compared with those values obtained from control cells and expressed as percentage of control. 

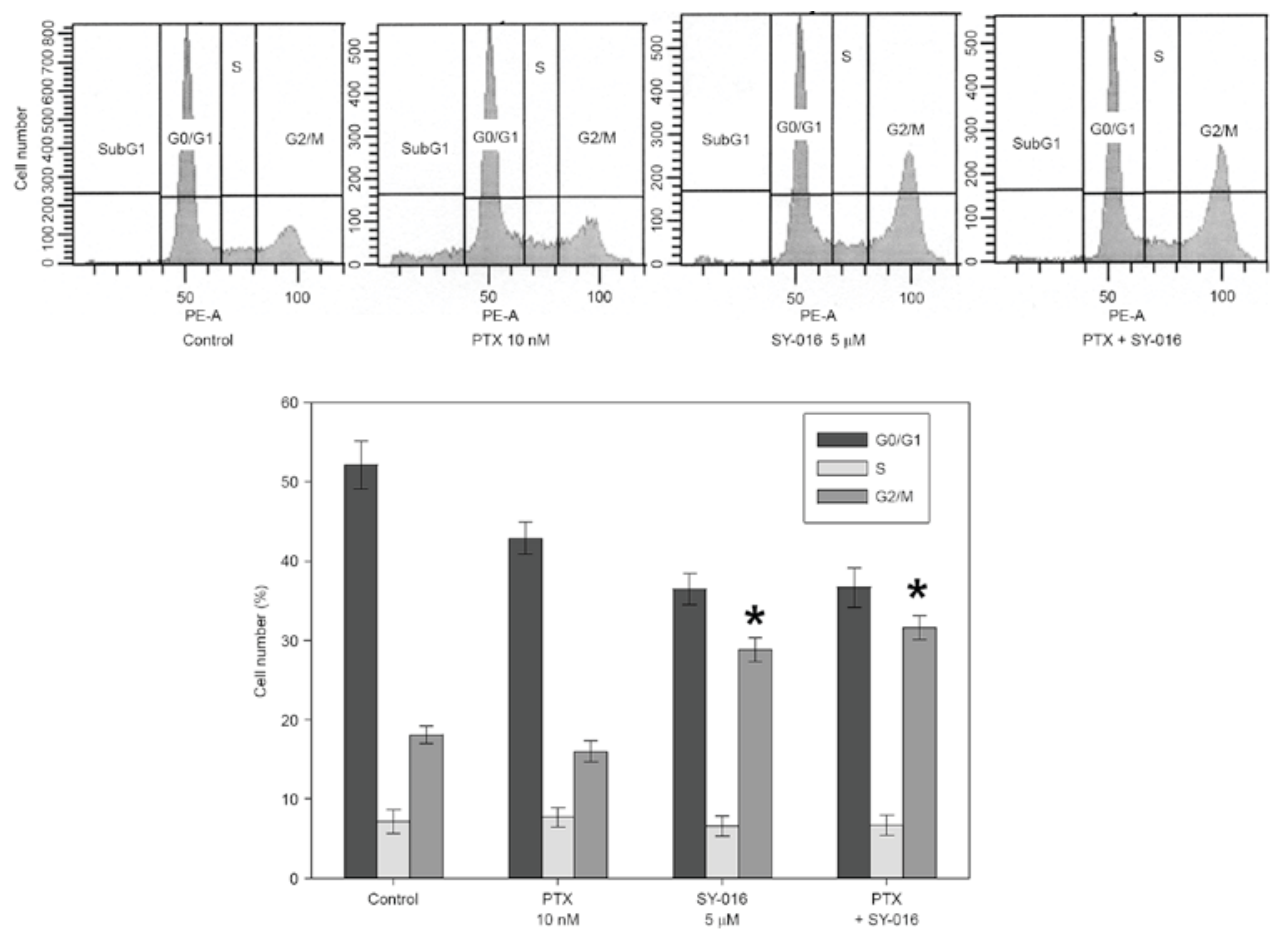

Figure 3. Effects of PTX and/or SY-016 on the cell cycle profile. After treatment with PTX and/or SY-016 for 48 h, OVCAR-3PTX cells were collected, fixed, stained with propidium iodide and analyzed by flow cytometry. The values represent the numbers of cells existing in the indicated phases of the cell cycle as a percentage of the total number of cells. G0/G1, S and G2/M are the phases of the cell cycle. Values are means \pm standard deviation of three measurements ${ }^{*} \mathrm{P}<0.05$. PTX, paclitaxel.

A

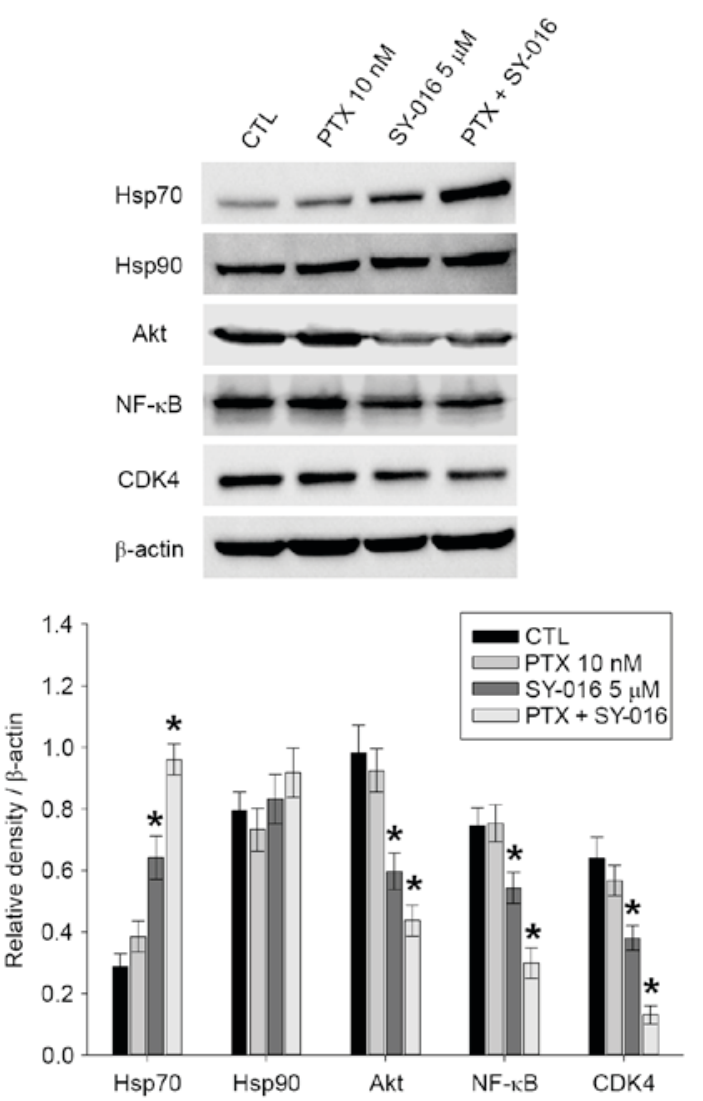

B
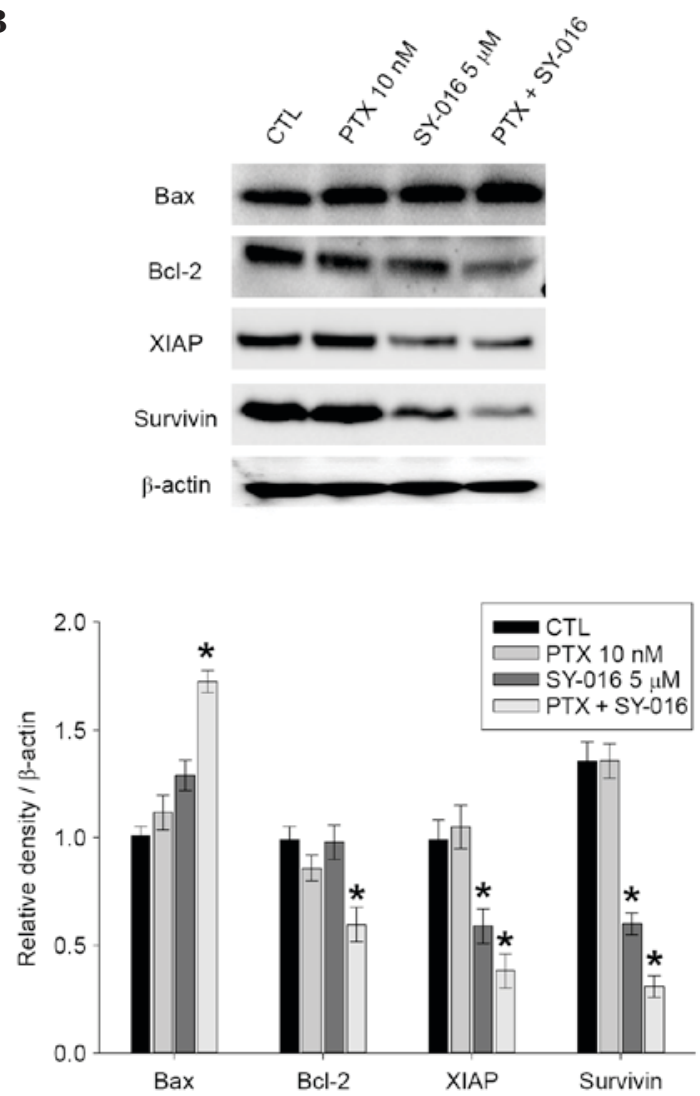

Figure 4. Effects of PTX and/or SY-016 on the expression of apoptosis-related proteins in OVCAR-3PTX cells. (A) Western blot analysis of Hsp70, Hsp90, Akt, NF-kB and CDK4 expression in OVCAR-3PTX cells after treatment with PTX and/or SY-016 for $48 \mathrm{~h}$. (B) Western blot analysis of Bcl-2, XIAP, survivin and Bax in OVCAR-3PTX cells after treatment with PTX and/or SY-016 for $48 \mathrm{~h}$. $\beta$-Actin was used as an internal loading control. Each band was quantified by densitometric analysis and presented in a bar graph. Values are means \pm standard deviation of three measurements ${ }^{*} \mathrm{P}<0.05$. PTX, paclitaxel; CTL, control; Bcl, B-cell lymphoma; Hsp, heat shock protein; NF, nuclear factor; CDK, cyclin-dependent kinase; Bax, Bcl-2-associated X protein; XIAP, X-linked inhibitor of apoptosis protein. 

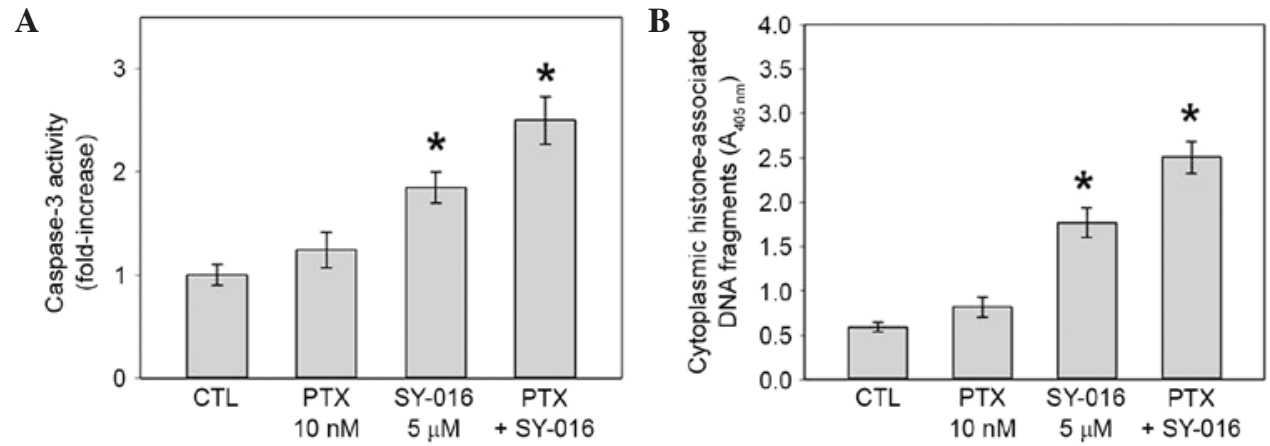

Figure 5. Induction of apoptosis following treatment of OVCAR-3PTX cells with PTX and/or SY-016. Cells were exposed to PTX and/or SY-016 for 48 h. Apoptosis was quantified by (A) caspase-3 activity and (B) ELISA. Values are means \pm standard deviation of three measurements *P<0.05. PTX, paclitaxel; CTL, control; A, absorbance.

Statistical analysis. The data are presented as the mean \pm SD. Statistical analysis was conducted using one-way analysis of variance followed by Duncan's multiple range test for post hoc comparison with SPSS 17.0 (SPSS Inc., Chicago, IL, USA). $\mathrm{P}<0.05$ was considered to indicate a statistically significant difference.

\section{Results}

Inhibitory effect of SY-016 on chemoresistant ovarian cancer cell proliferation. The potential of SY-016 to inhibit the growth of ovarian cancer cells and chemoresistant ovarian cancer cells was determined by MTT assay. PTX $(10 \mathrm{nM})$ alone inhibited the growth of OVCAR-3 and OVCAR-3PTX cells by 25 and $2 \%$, respectively. The percentages of inhibition of growth of OVCAR-3 and OVCAR-3PTX cells by PTX combined with SY-016 $(5 \mu \mathrm{M})$ were 68 and 59\%, respectively (Fig. 2A). Based on these data, $10 \mathrm{nM}$ PTX and $5 \mu \mathrm{M}$ SY-016 were employed in all subsequent experiments. Cisplatin $(10 \mu \mathrm{M})$ inhibited the growth of A2780 and A2780cis cells by 33 and $5 \%$, respectively. The proliferation of A2780 and A2780cis cells was inhibited by 65 and 39\%, respectively, when cisplatin was administered in combination with SY-016 (5 $\mu \mathrm{M})$ (Fig. 2B).

SY-016 causes G2/M arrest in OVCAR-3PTX cells. To identify the mechanism of cell growth inhibition by combined treatment with PTX and SY-016, the effects of these drugs on the cell cycle distribution were examined by flow cytometry. As shown in Fig. 3, the percentage of G2/M-phase cells in the control group was $18.1 \%$. In cells treated with PTX and SY-016, the percentage of $\mathrm{G} 2 / \mathrm{M}$-phase cells significantly increased to $31.6 \%$. These results indicate that the cell cycle arrest at the G2/M checkpoint was due to the growth inhibitory effect of SY-016 on PTX-resistant ovarian cancer cells.

Effects of $\mathrm{SY}-016$ on apoptotic signaling proteins in OVCAR-3PTX cells. Hsp90 is involved in the folding, stabilization and activation of its substrate proteins, which are collectively referred to as 'client' proteins. The present study examined whether SY-016 induced the degradation of Hsp90 client proteins in OVCAR-3PTX cells. Combination treatment with PTX and SY-016 significantly reduced the protein levels of Akt, NF- $\mathrm{B}$ and CDK4 (Fig. 4A). In addition, induction of Hsp70, a marker of Hsp90 inhibition (7), was also observed.
Combination treatment with PTX and SY-016 effectively downregulated Bcl-2, XIAP and survivin. By contrast, Bax was upregulated following the above combination treatment (Fig. 4B). These results suggest that SY-016 induced cell growth inhibition and apoptotic cell death in part via the inhibition of survival factors and inactivation of the $\mathrm{Akt} / \mathrm{NF}-\kappa \mathrm{B}$ pathway.

Induction of apoptotic cell death by PTX in combination with $S Y$-016. The activity of caspase-3, an executioner caspase of apoptosis (6), increased following combination treatment with PTX and SY-016 (Fig. 5A). The ELISA results revealed a significant increase in histone-associated DNA fragments after exposure to PTX and SY-016 for $48 \mathrm{~h}$ (Fig. 5B).

\section{Discussion}

Chemotherapy is considered as the standard treatment procedure for ovarian cancer (9). However, patients often fail to respond to chemotherapy, and relapse of the disease frequently occurs due to chemoresistance. These have become major obstacles in improving responses to the treatment of ovarian cancer. Cancer is a complex disease with several abnormally expressed oncogenic cellular proteins that activate multiple signaling pathways (12). Therefore, the use of chemoresistant cancer cell lines is one of the useful model systems to study molecular mechanisms leading to anticancer drug resistance (13).

The stability of the majority of oncogenes depends heavily on the chaperone function of Hsp90. For this reason, Hsp90 is an attractive therapeutic target in cancer therapy (14). The present study demonstrated that SY-016, a novel Hsp90 inhibitor, inhibited the growth of OVCAR-3PTX cells. Notably, combination treatment with PTX and SY-016 resulted in a significant decrease in the proliferation of OVCAR-3PTX cells and an increase in the percentage of apoptotic cells. Therefore, it is necessary to explore the possible underlying mechanisms that would explain these results.

Akt, also known as protein kinase B, is involved in cellular survival pathways by inhibiting apoptotic processes. Akt deregulation is also involved in the development of chemoresistance (15). NF- $\mathrm{BB}$ has been recognized as one of the most important targets of the Akt signaling pathway. The activation of NF- $\kappa \mathrm{B}$ is dependent on the phosphorylation of $\mathrm{I} \kappa \mathrm{B}$ under the control of the Akt kinase (16). Simultaneous activation of multiple signaling pathways contributes to a survival advantage 
in ovarian cancer cells, as well as to resistance to anticancer drugs. Furthermore, the Akt/NF- $\mathrm{BB}$ signaling pathway serves a key role in regulating cell growth, survival and chemoresistance in ovarian and gastric cancer cells $(17,18)$. Akt and $\mathrm{NF}-\kappa \mathrm{B}$ are involved in ovarian cancer chemoresistance through the upregulation of FLICE-inhibitory protein, XIAP, Bcl-2 and survivin (16). Similarly, reduced malignant potential was observed when NF- $\kappa \mathrm{B}$ was blocked in ovarian cancer cells (19). In this regard, inhibition of the Akt/NF- $\mathrm{B}$ pathway may represent a novel therapeutic strategy for the treatment of PTX-resistant ovarian cancer. The Hsp90 inhibitor SY-016 can block the expression of Akt and consequently inhibit the activation of NF- $\mathrm{KB}$. The present results demonstrated that SY-016, as a single agent and in combination with PTX, significantly decreased the expression of Akt and $\mathrm{NF}-\kappa \mathrm{B}$ compared with PTX alone. Additionally, combination treatment with PTX and SY-016 blocked the Akt/NF- $\kappa$ B pathway, resulting in apoptosis and growth inhibition of tumor cells.

SY-016 caused cell-cycle arrest in G2/M phase in OVCAR-3PTX cells. As the percentage of cells in G2/M phase increased, the percentage of cells in the G0/G1 and $\mathrm{S}$ phases decreased and slightly changed, respectively. This indicates that G2/M-phase arrest may be a mechanism by which SY-016 inhibited PTX-resistant ovarian cancer cell growth. Additional studies are required to investigate the molecular mechanism underlying the G2/M arrest observed in OVCAR-3PTX cells.

In the current study, SY-016 not only inhibited the cell growth and cell cycle progression of OVCAR-3PTX cells, but also induced cell apoptosis. Recent studies have demonstrated apoptotic effects of Hsp90 inhibitors on human leukemia cells (20). Furthermore, cancer cell-specific apoptotic effects of Hsp90 inhibitors were documented in breast and colorectal cancer cells $(21,22)$. These findings indicate that cell growth inhibition induced by Hsp90 inhibitors is mediated through an apoptosis-dependent mechanism.

The present study has demonstrated that SY-016 suppressed the proliferation of OVCAR-3PTX cells by inducing apoptosis, coupled with augmented G2/M-phase arrest and DNA fragmentation. These results provide initial evidence for testing the combination treatment of PTX and SY-016 for clinical use. Therefore, these findings support the development of preclinical experiments using animal models to further evaluate the potential application of SY-016 in the treatment of PTX-resistant ovarian cancer.

\section{Acknowledgements}

The present study was supported by the Bisa Research Grant of Keimyung University (Jung-gu, Korea) awarded in 2013.

\section{References}

1. Jemal A, Siegel R, Ward E, Hao Y, Xu J and Thun MJ: Cancer statistics, 2009. CA Cancer J Clin 59: 225-249, 2009.

2. Mayerhofer K, Kucera E, Zeisler H, Speiser P, Reinthaller A and Sevelda P: Taxol as second-line treatment in patients with advanced ovarian cancer after platinum-based first-line chemotherapy. Gynecol Oncol 64: 109-113, 1997.

3. Horwitz SB, Lothstein L, Manfredi JJ, Mellado W, Parness J, Roy SN, Schiff PB, Sorbara L and Zeheb R: Taxol: Mechanisms of action and resistance. Ann N Y Acad Sci 466: 733-744, 1986.
4. Karaca B, Atmaca H, Bozkurt E, Kisim A, Uzunoglu S, Karabulut B, Sezgin C, Sanli UA and Uslu R: Combination of AT-101cisplatin overcomes chemoresistance by inducing apoptosis and modulating epigenetics in human ovarian cancer cells. Mol Biol Rep 40: 3925-3933, 2013.

5. Kajiyama H, Shibata K, Terauchi M, Yamashita M, Ino K, Nawa A and Kikkawa F: Chemoresistance to paclitaxel induces epithelial-mesenchymal transition and enhances metastatic potential for epithelial ovarian carcinoma cells. Int J Oncol 31: 277-283, 2007.

6. Whitesell L and Lindquist SL: HSP90 and the chaperoning of cancer. Nat Rev Cancer 5: 761-772, 2005.

7. Proia DA, Sang J, He S, Smith DL, Sequeira M, Zhang C, Liu Y, Ye S, Zhou D, Blackman RK, et al: Synergistic activity of the Hsp90 inhibitor ganetespib with taxanes in non-small cell lung cancer models. Invest New Drugs 30: 2201-2209, 2012.

8. Pandey P, Saleh A, Nakazawa A, Kumar S, Srinivasula SM Kumar V, Weichselbaum R, Nalin C, Alnemri ES, Kufe D and Kharbanda S: Negative regulation of cytochrome c-mediated oligomerization of Apaf-1 and activation of procaspase- 9 by heat shock protein 90. EMBO J 19: 4310-4322, 2000.

9. Fraser M, Leung B, Jahani-Asl A, Yan X, Thompson WE and Tsang BK: Chemoresistance in human ovarian cancer: The role of apoptotic regulators. Reprod Biol Endocrinol 1: 66, 2003.

10. Ono N, Yamazaki T, Tsukaguchi T, Fujii T, Sakata K, Suda A, Tsukuda T, Mio T, Ishii N, Kondoh O and Aoki Y: Enhanced antitumor activity of erlotinib in combination with the Hsp90 inhibitor CH5164840 against non-small-cell lung cancer. Cancer Sci 104: 1346-1352, 2013.

11. Parajuli B, Lee HG, Kwon SH, Cha SD, Shin SJ, Lee GH, Bae I

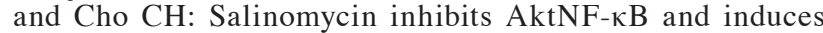
apoptosis in cisplatin resistant ovarian cancer cells. Cancer Epidemiol 37: 512-517, 2013.

12. Karkoulis PK, Stravopodis DJ, Konstantakou EG and Voutsinas GE: Targeted inhibition of heat shock protein 90 disrupts multiple oncogenic signaling pathways, thus inducing cell cycle arrest and programmed cell death in human urinary bladder cancer cell lines. Cancer Cell Int 13: 11, 2013.

13. Zhang X, Yashiro M, Qiu H, Nishii T, Matsuzaki T and Hirakawa K: Establishment and characterization of multidrug-resistant gastric cancer cell lines. Anticancer Res 30: 915-921, 2010.

14. Hahn JS: The Hsp90 chaperone machinery: From structure to drug development. BMB Rep 42: 623-630, 2009.

15. Sun ZJ, Chen G, Hu X, Zhang W, Liu Y, Zhu LX, Zhou Q and Zhao YF: Activation of PI3KAktIKK-alphaNF-kappaB signaling pathway is required for the apoptosis-evasion in human salivary adenoid cystic carcinoma: Its inhibition by quercetin. Apoptosis 15: 850-863, 2010

16. Yang YI, Lee KT, Park HJ, Kim TJ, Choi YS, Shih IeM and Choi JH: Tectorigenin sensitizes paclitaxel-resistant human ovarian cancer cells through downregulation of the Akt and NFkB pathway. Carcinogenesis 33: 2488-2498, 2012.

17. Oki E, Baba H, Tokunaga E, Nakamura T, Ueda N, Futatsugi M, Mashino K, Yamamoto M, Ikebe M, Kakeji Y and Maehara Y: Akt phosphorylation associates with LOH of PTEN and leads to chemoresistance for gastric cancer. Int J Cancer 117: 376-380, 2005.

18. Shin JY, Kim JO, Lee SK, Chae HS and Kang JH: LY294002 may overcome 5-FU resistance via down-regulation of activated p-AKT in Epstein-Barr virus-positive gastric cancer cells. BMC Cancer 10: 425, 2010.

19. Huang S, Robinson JB, Deguzman A, Bucana CD and Fidler IJ: Blockade of nuclear factor-kappaB signaling inhibits angiogenesis and tumorigenicity of human ovarian cancer cells by suppressing expression of vascular endothelial growth factor and interleukin 8. Cancer Res 60: 5334-5339, 2000.

20. Jin L, Xiao CL, Lu CH, Xia M, Xing GW, Xiong S, Liu QY, Liu H, $\mathrm{Li} \mathrm{YC}, \mathrm{Ge} \mathrm{F}$, et al: Transcriptomic and proteomic approach to studying SNX-2112-induced K562 cells apoptosis and anti-leukemia activity in K562-NODSCID mice. FEBS Lett 583: 1859-1866, 2009.

21. Wainberg ZA, Anghel A, Rogers AM, Desai AJ, Kalous O, Conklin D, Ayala R, O'Brien NA, Quadt C, Akimov M, et al: Inhibition of HSP90 with AUY922 induces synergy in HER2-amplified trastuzumab-resistant breast and gastric cancer. Mol Cancer Ther 12: 509-519, 2013.

22. Saturno G, Valenti M, De Haven Brandon A, Thomas GV, Eccles S Clarke PA and Workman P: Combining trail with PI3 kinase or HSP90 inhibitors enhances apoptosis in colorectal cancer cells via suppression of survival signaling. Oncotarget 4: 1185-1198, 2013. 